\title{
Fasudil Stimulates Neurite Outgrowth and Promotes Differentiation in C17.2 Neural Stem Cells by Modulating Notch Signalling but not Autophagy
}

\author{
Shu Chen ${ }^{a}$ Ming Luo ${ }^{b}$ Yuming Zhao ${ }^{c}$ Yimin Zhang ${ }^{d}$ Mingliang $\mathrm{He}^{\mathrm{a}}$ \\ Wangqing Cai ${ }^{\mathrm{a}}$ Anmin $\mathrm{Liu}^{\mathrm{a}}$
}

\begin{abstract}
aDepartment of Neurosurgery, SunYat-sen Memorial Hospital, SunYat-sen University, Guangzhou, China, 'bepartment of Oncology, SunYat-sen Memorial Hospital, SunYat-sen University, Guangzhou, China, 'Department of Pharmacology, Capital Medical University, Beijing, China, dJinan University, Guangzhou, China
\end{abstract}

\section{Key Words}

Fasudil $\bullet$ Neural stem cell $\bullet$ Neurite outgrowth $\bullet$ Differentiation $\bullet$ Notch signaling $\bullet$ Autophagy

\begin{abstract}
Background: Neurite outgrowth is one of the important therapeutic strategies for neuronal plasticity and regeneration in neural disorders. Fasudil is a clinical medication that is used to treat subarachnoid haemorrhage $(\mathrm{SAH})$ and that is beneficial for many animal models of central nervous system (CNS) diseases. In this study, we hypothesised that fasudil administration would promote neurite outgrowth in neural stem cells (NSCs). Methods: Changes in cell morphology were imaged under a light microscope, and neurite-bearing cells were counted. Cell viability and the necrosis rate were determined by MTT and LDH assays, respectively. Additionally, western blot and immunofluorescence analyses were performed to detect protein expression levels. Results: We found that fasudil promoted neurite outgrowth in C17.2 cells in a time- and dose-dependent manner. The neurite-bearing C17.2 cells were differentiated by detecting the changes in neural and astrocytic markers after fasudil treatment through downregulating Notch signalling. Previously, fasudil was reported to induce autophagy, which plays an important role in neural differentiation. However, both rapamycin, an autophagy inducer, and 3-methyl-adenine (3-MA), an autophagy inhibitor, had no effects on the fasudilinduced neurite outgrowth, suggesting that autophagy may be not involved in this process. Conclusion: In summary, fasudil could stimulate neurite outgrowth and differentiation in C17.2 cells by modulating Notch signalling but not autophagy.
\end{abstract}

S. Chen and M. Luo contributed equally to this study.

Anmin Liu,

KARGER 125
Department of Neurosurgery, SunYat-sen Memorial Hospital, SunYat-sen University. Yanjiang West Road 107, Guangzhou 510120 (China)

Tel. +86-20-81332016, E-Mail liuanmin@mail.sysu.edu.cn 


\section{Cellular Physiology Cell Physiol Biochem 2015;36:531-541 \begin{tabular}{l|l|}
\hline DOI: 10.1159/000430118 & O 2015 S. Karger AG, Basel
\end{tabular} and Biochemistry Published online: May 18, 2015 www.karger.com/cpb \\ Chen et al.: Fasudil Promotes C17.2 Cells Neurite Outgrowth and Differentiation}

\section{Introduction}

Various cellular functions are induced by Rho kinase (ROCK), which plays a crucial role in cytoskeleton construction. One of its inhibitors, fasudil, is a potent vasodilator that has been applied as a clinical medication for treating SAH. Currently, increasingly new effects of fasudil have been discovered, particularly in the CNS. New evidence has shown that fasudil can suppress the proliferation, migration and invasion abilities of the glioblastoma cell lines T98G and U251 [1]. Moreover, the ROCK and mitogen-activated protein kinase/extracellular signal-regulated kinase (MEK/ERK) signalling pathways are involved in the anti-tumour effects caused by fasudil [2]. Subcutaneous injection of hydroxyfasudil improves learning and working memory, which provides new insight into improving the prognosis of Alzheimer's disease (AD) [3]. Additionally, the role of this medication in preventing neurodegeneration may be due to its contribution to promoting NSC proliferation and differentiation $[4,5]$. Neuronal differentiation could improve neurological function in stroke models [6] and traumatic brain injury models [7]. Fasudil can maintain and improve neurologic functions during various internal environment disturbances, which may be due to its ability to promote neurite outgrowth [8-10]. Previous reports have shown that autophagy may be involved in neurite outgrowth and cell differentiation $[11,12]$. Furthermore, using an automatic analysis of the topology of the drug network, Iorio et al found that one of the unexpected effects of fasudil is autophagy induction $[13,14]$.

The Notch signalling pathway is essential for maintaining NSCs in the developing brain and plays a crucial role in NSC proliferation and differentiation [15-17]. Neurite development is also influenced by Notch signalling in vitro [18]. Hes 1, which belongs to the basic helix-loophelix family of transcription factors, plays an important role in the Notch signalling pathway [19]. Additionally, Hes 1 regulates its own expression through a feedback loop and oscillates with an approximately 2-hour periodicity [20]. Both Notch 1 and Hes 1 are repressors that influence the NSC fate decision [21]. The activation of these repressors maintains NSCs in a proliferating state, whereas decreasing the expression of these repressors promotes NSC differentiation and depletion [22]. Moreover, the dysfunction of the Notch signalling pathway is associated with neurodegenerative diseases such as AD [23].

In this study, we hypothesised that fasudil would promote neurite outgrowth in C17.2 NSCs and examined whether the Notch signalling pathway and autophagy were involved in the fasudil-induced neurite outgrowth of NSCs. We found that fasudil could stimulate neurite outgrowth and neuronal differentiation in C17.2 cells through modulating Notch signalling but not autophagy.

\section{Materials and Methods}

\section{Cell culture and reagents}

The C17.2 cell line, which is composed of neural stem cells that were derived from the external germinal layer of mouse cerebellum [24], was a kind gift presented by Dr. Yuming Zhao of Capital Medical University, China. Fasudil (purity $>98.0 \%$ ) was purchased from Melonepharma (Dalian, China), dissolved in PBS and stored at $-20^{\circ} \mathrm{C}$. Dulbecco's modified Eagle's medium (DMEM) and foetal bovine serum (FBS) were obtained from Gibco-BRL (NY, USA). Trypsin, dimethyl sulfoxide (DMSO), 3-(4,5-dimethylthiazol-2-yl)-2,5diphenyltetrazolium bromide (MTT), Hoechst 33258, glutamine, the autophagy inducer rapamycin and the autophagy inhibitor 3-MA were purchased from Sigma-Aldrich (MO, USA).

C17.2 cells were maintained in plastic culture flasks in complete DMEM [25], which is DMEM containing $10 \%$ FBS, 5\% horse serum, and $2 \mathrm{mM}$ glutamine, in an incubator with a humidified 5\% $\mathrm{CO}_{2} 95 \%$ air atmosphere at $37^{\circ} \mathrm{C}$. The cells were passaged after they reached $80 \%$ confluence.

C17.2 cells were treated with fasudil at various concentrations $(0,25,50$ and $100 \mu \mathrm{M})$ for different periods $(1,3,6,12,24$ and $48 \mathrm{~h})$ to analyse dose- and time-dependent neurite outgrowth. Cell morphological 


\section{Cellular Physiology Cell Physiol Biochem 2015;36:531-541 \begin{tabular}{l|l|l}
$\overline{D O I}: 10.1159 / 000430118$ & $O$ & 2015 S. Karger AG, Basel
\end{tabular} and Biochemistry Published online: May 18, 2015 www.karger.com/cpb \\ Chen et al.: Fasudil Promotes C17.2 Cells Neurite Outgrowth and Differentiation}

changes were observed under a phase contrast microscope at a magnification of $200 \times$. Neurite outgrowth was defined as a process with a length greater than twofold the cell body diameter as described previously [11]. Then, the percentage of cells with neurite outgrowth was quantified for 300 cells per well in randomly chosen fields ( $n=3$ /group). Next, the stimuli were removed, and the cells were cultured in complete DMEM for $12 \mathrm{~h}$. Then, percentage of remaining neurite outgrowth cells was calculated again ( $n=3$ /group).

\section{Assessment of cell viability by MTT assay}

Cell viability was determined by MTT assay. Briefly, cells $\left(1 \times 10^{4}\right.$ cells/well $)$ were seeded in 96-well plates and incubated in complete DMEM for $24 \mathrm{~h}$ before being treated with fasudil. MTT ( $5 \mathrm{~g} / \mathrm{L}, 10 \mu \mathrm{L})$ was added to each well, and then the cells were cultured in the incubator for $2 \mathrm{~h}$, followed by the removal of the culture medium and the addition of $100 \mu \mathrm{L}$ of DMSO. The absorbance was measured at $570 \mathrm{~nm}$, with 655 $\mathrm{nm}$ as the reference wavelength. All experiments were performed in triplicate.

\section{LDH release assay}

C17.2 cells were plated in 96-well plates at a density of $1 \times 10^{4}$ per well. On the following day, the cells were exposed to various concentrations of fasudil for $24 \mathrm{~h}$. The medium was collected and assayed for lactate dehydrogenase (LDH) activity using a Lactate Dehydrogenase Assay Kit (Nanjing, China). Also the intracellular LDH activity was measured as previously described with some modifications [26]. After treatment with or without fasudil at various concentrations for $24 \mathrm{~h}$, the cells were incubated with 0.2 $\%$ Triton $\mathrm{X}-100$ at $37^{\circ} \mathrm{C}$ for $30 \mathrm{~min}$ with shaking (800rpm). The cell lysates were collected. Briefly, LDH release is measured by a coupled enzymatic reaction that results in the conversion of a tetrazolium salt into red formazan product. The amount of formazan synthesised correlates with LDH activity. The formazan product was measured using a microplate reader at $450 \mathrm{~nm}$. The results are expressed as the percentage of LDH release. And the absorbance of control cells was set at $100 \%$.

\section{Western blot}

The protein levels of Notch 1 (Cell Signaling Technology, 1:1000 dilution), Hes 1 (Cell Signaling Technology, 1:1000 dilution), the NSC marker Nestin (Abcam, 1:1000 dilution), the immature neuronal cell marker doublecortin (DCX; Cell Signaling Technology, 1:1000 dilution), the mature neuronal cell marker microtubule-associated protein (MAP-2; Boster, 1:500 dilution), the astrocytic marker glial fibrillary acidic protein (GFAP; Cell Signaling Technology, 1:1000 dilution), and the autophagy markers P62 (Cell Signaling Technology, 1:1000 dilution) and LC3 (Cell Signaling Technology, 1:1000 dilution) in C17.2 cells were examined by western blot analysis.

Cells were harvested at the indicated time points and then incubated in radio immunoprecipitation assay lysis buffer with a protease inhibitor tablet for $30 \mathrm{~min}$ at $4^{\circ} \mathrm{C}$. Cell lysates were centrifuged at 20,000 g at $4^{\circ} \mathrm{C}$ for $15 \mathrm{~min}$, and the supernatant was collected and stored at $-20^{\circ} \mathrm{C}$ for further analysis by western blot. Protein extracts $(20 \mu \mathrm{g}$, quantitation performed by the bicinchoninic acid method, Thermo Scientific) were fractionated by electrophoresis on $10 \%$ and $15 \%$ polyacrylamide gels and transferred to PVDF membranes. After the membranes were blocked in 5\% skim milk at room temperature for $1 \mathrm{~h}$, they were incubated with primary antibodies overnight at $4^{\circ} \mathrm{C}$. Then, the membranes were incubated with secondary bodies (Thermo Scientific) for $2 \mathrm{~h}$ at room temperature. The same membranes were also incubated with anti- $\alpha$ tubulin or anti- $\beta$-actin as loading controls. Proteins were detected using an ECL kit (Thermo Scientific) and a chemiluminescence imaging system (ChemiScope5600, CLINX) in a dark room at $24^{\circ} \mathrm{C}$, and signals were quantified using scanning densitometry.

\section{Immunofluorescence}

C17.2 cells were fixed in $4 \%$ paraformaldehyde for 30 minutes at room temperature after being treated with fasudil $(100 \mu \mathrm{M})$ for 24 hs. Then, the cells were incubated with $0.3 \%$ Triton X-100 for 15 minutes to permeabilize the cell membranes before the cells were blocked in normal goat serum for $1 \mathrm{~h}$ at room temperature. Then, the cells were incubated with primary antibodies (Nestin, 1:500 dilution; DCX, 1:400 dilution; MAP-2, 1:400 dilution; GFAP, 1:400 dilution) at $4^{\circ} \mathrm{C}$ overnight. Subsequently, the cells were incubated with Alexa Fluor 555-conjugated secondary antibody (1:500) for $1 \mathrm{~h}$ at room temperature. The cells were counterstained with Hoechst 33258 to visualise nuclei. Images were acquired using a fluorescence microscope (Olympus $63 \times$ oil lens, Japan) equipped with a UV filter in a dark room at $24^{\circ} \mathrm{C}$ ( $\mathrm{n}=3 /$ group). 


\section{Cellular Physiology Cell Physiol Biochem 2015;36:531-541 \begin{tabular}{l|l|}
\hline DOI: 10.1159/000430118 & O 2015 S. Karger AG, Basel \\
\hline
\end{tabular} and Biochemistry Published online: May 18, $2015 \quad$ www.karger.com/cpb}

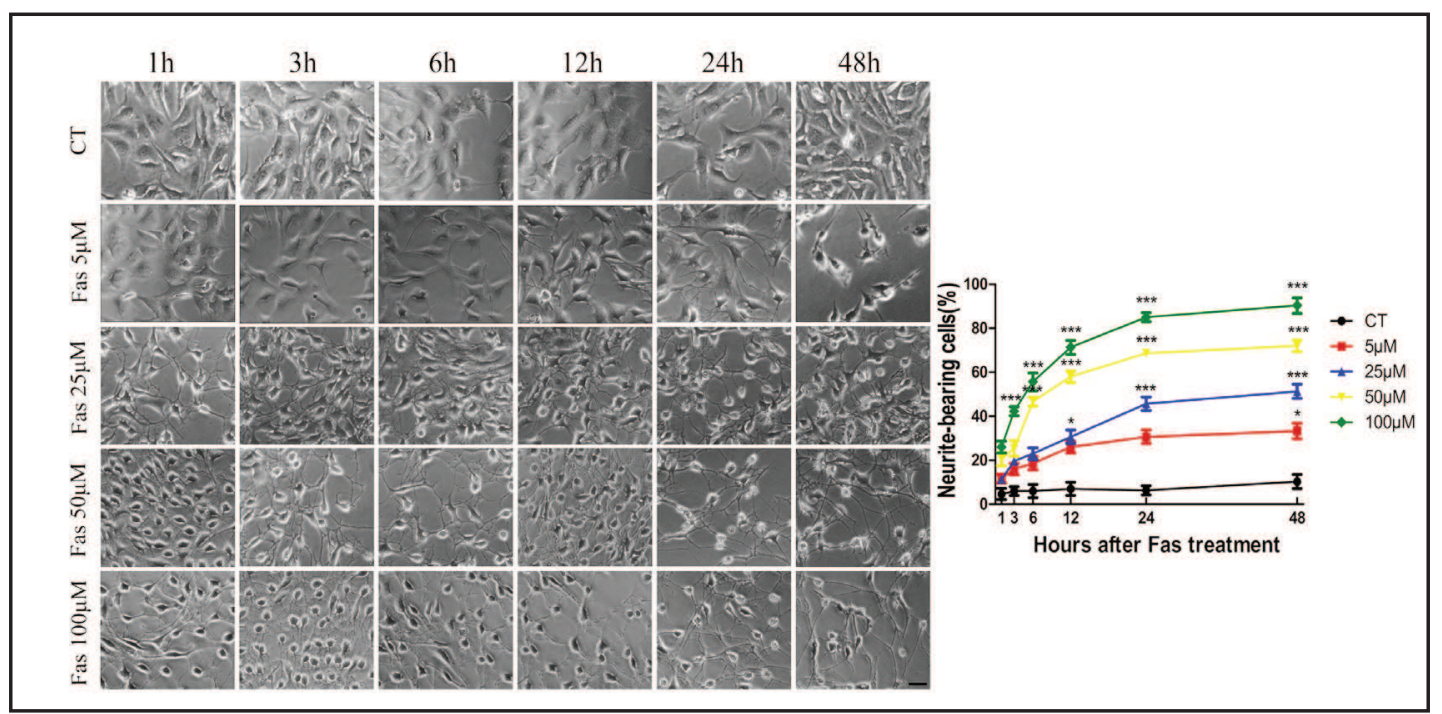

Fig. 1. Fasudil promotes the neurite outgrowth of C17.2 cells in a time- and dose-dependent manner. C17.2 cells were stimulated with different concentrations ( $5 \mu \mathrm{M}, 25 \mu \mathrm{M}, 50 \mu \mathrm{M}$ and $100 \mu \mathrm{M})$ of fasudil for different periods $(1,3,6,12,24$ and $48 \mathrm{~h})$. Cell morphology was observed under a light microscope (200x), and the neurite-bearing cells with neurite lengths greater than twofold the cell body diameter were counted. ${ }^{*} p<0.05$ and ${ }^{* * *} p<0.01$ compared with the time-matched control group (CT). Scale bar $=50 \mu \mathrm{m}$.

\section{Statistical analysis}

The data are presented as the means \pm standard error. Statistical analyses between two groups were performed using unpaired Student's t-test. Differences among groups were tested by one-way analysis of variance (ANOVA). Following ANOVA analyses, Tukey's test was used, and $p<0.05$ was considered statistically significant.

\section{Results}

Fasudil induced neurite outgrowth in C17.2 cells

We examined the effect of fasudil on neurite outgrowth in C17.2 cells. After the cells were treated with fasudil for $1 \mathrm{~h}$, the ratio of neurite-bearing cells obviously and rapidly increased, except for the cells that were treated with $5 \mu \mathrm{M}$ of fasudil (Fig. 1), which displayed a slow increase in the ratio of neurite-bearing cells in a time-dependent manner when compared with the untreated control group. However, when compared with dose-matched, untreated cells, the percentage of neurite-bearing cells rapidly increased with 1, 3, 6, 12 and $24 \mathrm{~h}$ of persistent treatment but mildly increased from 24 to $48 \mathrm{~h}$ in different concentrations of fasudil. In contrast, when compared with time-matched, untreated cells, the percentage of neurite-bearing cells increased 3.4-, 4.3-, 6.7- and 8.8-fold following stimulation with fasudil for $48 \mathrm{~h}$ at concentrations of 5, 25, 50 and $100 \mu \mathrm{M}$, respectively. At the end of the treatment periods, the stimuli were removed, and the culture medium was returned to complete DMEM for $12 \mathrm{~h}$. Then, the percentage of remaining neurite-bearing cells was calculated for dose- and time-dependent treatments with fasudil (Fig. 2). Compared with time-matched, untreated cells, the percentage of remaining neurite-bearing cells after treatment with 100 $\mu \mathrm{M}$ fasudil was significantly greater $(p<0.01)$ at different time points. Based on these data, we chose the concentration of $100 \mu \mathrm{M}$ fasudil for the subsequent experiments.

Fasudil was not cytotoxic to C17.2 cells

The C17.2 cells were incubated with various concentrations of fasudil for $24 \mathrm{~h}$, and then cell viability was measured by MTT assay. As shown in Fig. 3B, the net absorbance at $570 \mathrm{~nm}$ significantly decreased in cells treated with $50 \mu \mathrm{M}$ and $100 \mu \mathrm{M}$ fasudil $(p<0.05)$ 


\section{Cellular Physiology Cell Physiol Biochem 2015;36:531-541 \begin{tabular}{l|l|}
\hline DOI: 10.1159/000430118 & O 2015 S. Karger AG, Basel
\end{tabular} and Biochemistry Published online: May 18, $2015 \quad$ www.karger.com/cpb

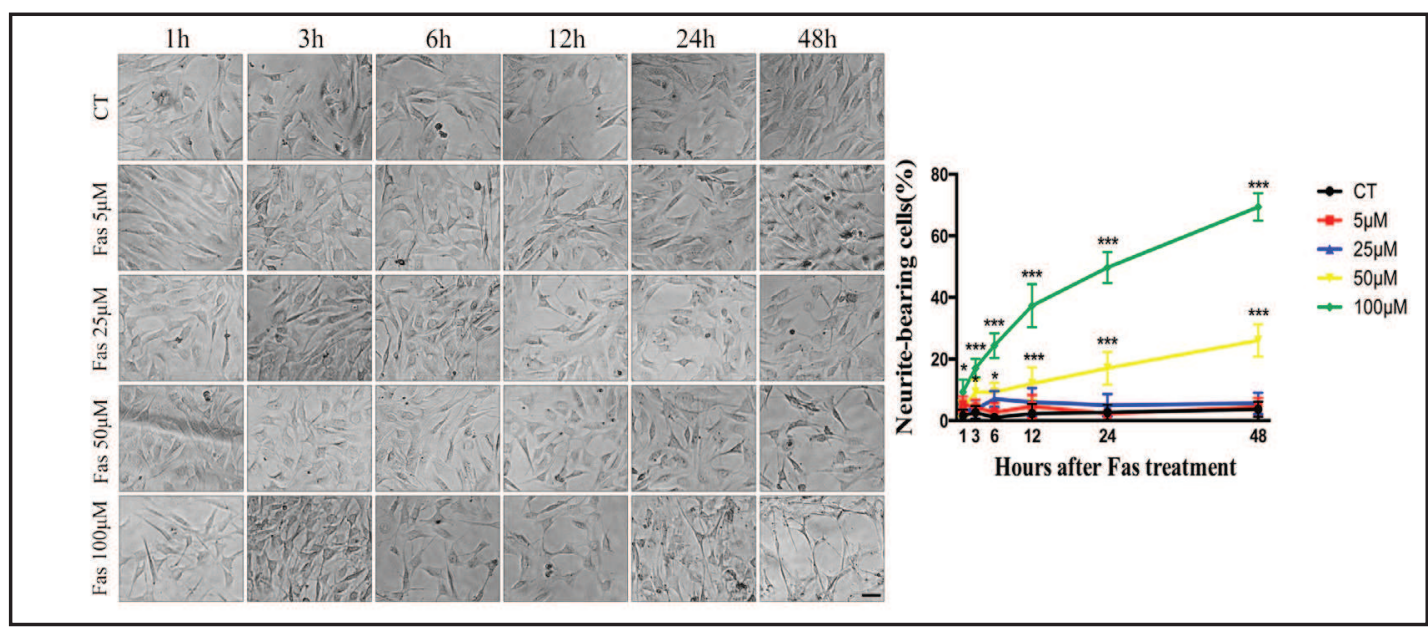

Fig. 2. The ratio of remaining neurite-bearing cells. After fasudil treatment, the stimulation was removed, and the medium was changed back to the complete DMEM. The cells were incubated for $12 \mathrm{~h}$, and then the remaining neurite-bearing cells with neurite lengths greater than twofold the cell body diameter were counted and compared with the stimulated time-matched control. Cell morphology changes were observed under a light microscope $(200 \times) .{ }^{*} p<0.05$ and ${ }^{* * *} p<0.01$ compared with the time-matched control group (CT). Scale bar $=50 \mu \mathrm{m}$

A

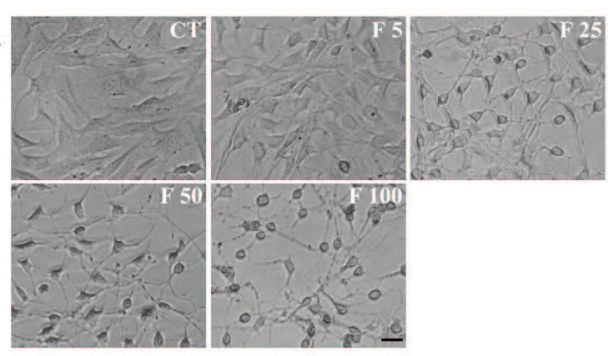

C

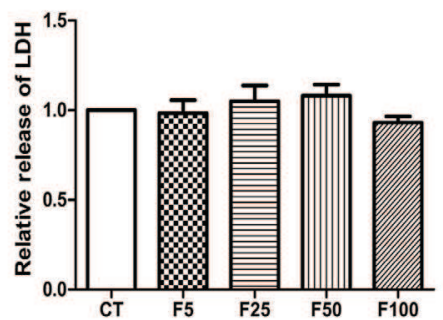

B

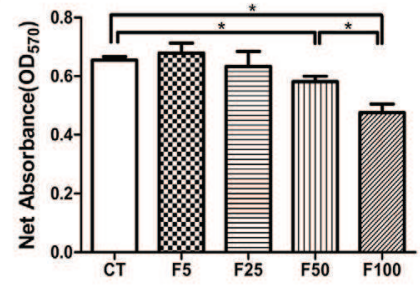

D

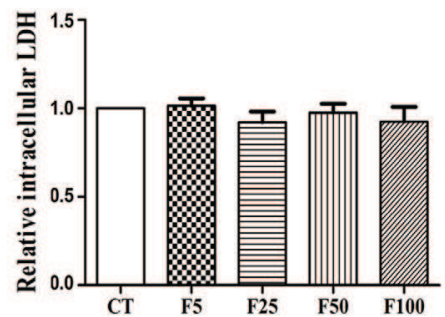

Fig. 3. Fasudil was not cytotoxic to C17.2 cells. After the cells were treated with fasudil for $24 \mathrm{~h}$, they were imaged under phase-contrast optics $(200 \times)$ (A). Cell viability was examined by MTT assay (B); lower concentrations ( $5 \mu \mathrm{M}$ and $25 \mu \mathrm{M}$ ) of fasudil had no influence on cell viability. However, cell viability was partially inhibited by middle and higher concentrations (50 $\mu \mathrm{M}$ and $100 \mu \mathrm{M})$ of fasudil. No differences were observed in the LDH assay (C/D). ${ }^{*} p<0.05$. Scale bar $=50 \mu \mathrm{m}$. Control group (CT).

compared with untreated cells. When compared with cells treated with $50 \mu \mathrm{M}$ fasudil, the net absorbance also clearly decreased in cells treated with $100 \mu$ M fasudil $(p<0.05)$. However, no differences were found in the LDH assay (Fig. 3C/D), indicating that fasudil was not cytotoxic to the C17.2 cells in our research.

Fasudil promoted C17.2 cell to differentiate into neuronal cells and astrocytes

C17.2 cells differentiated into neuronal cells and astrocytes as detected by western blot and immunofluorescence analyses (Fig. 4). The expression of the NSC marker Nestin 


\section{Cellular Physiology Cell Physiol Biochem 2015;36:531-541 \begin{tabular}{l|l}
\hline DOI: 10.1159/000430118 & O 2015 S. Karger AG, Basel
\end{tabular}

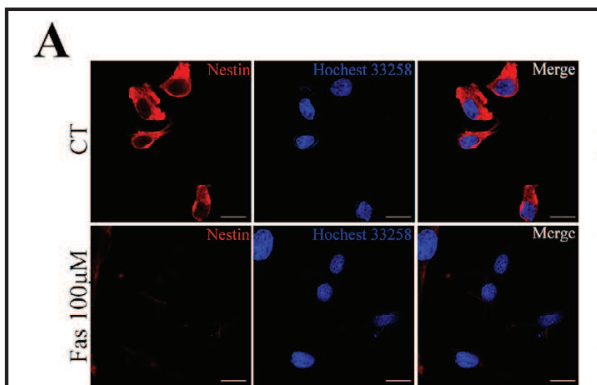

C

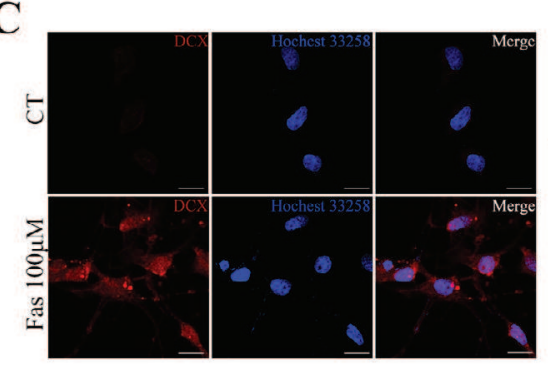

$\mathbf{E}$

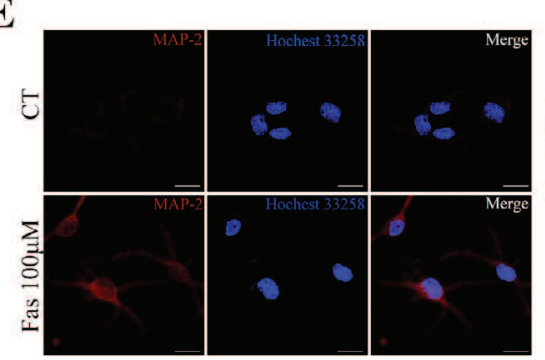

G

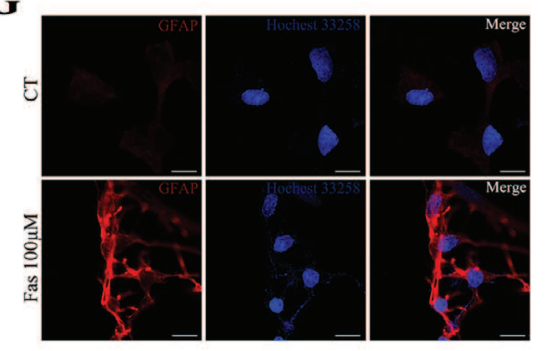

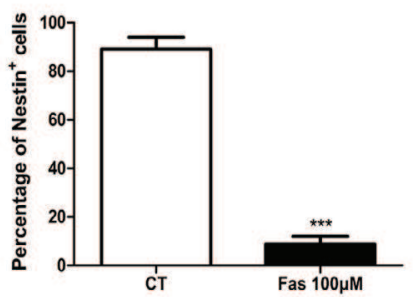

D
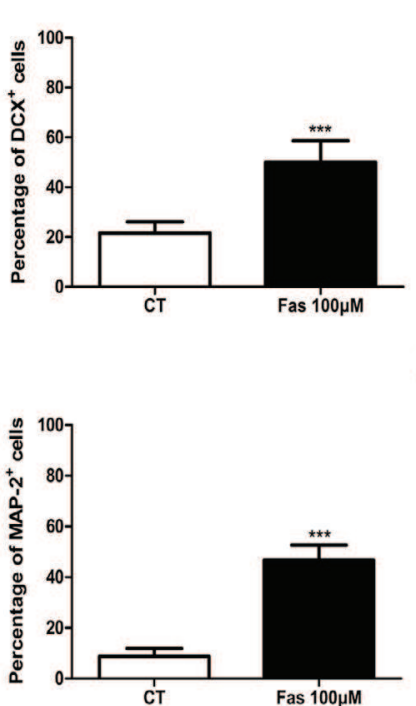

H

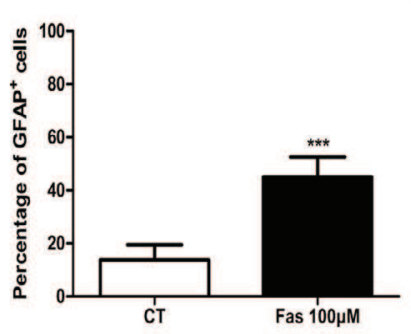

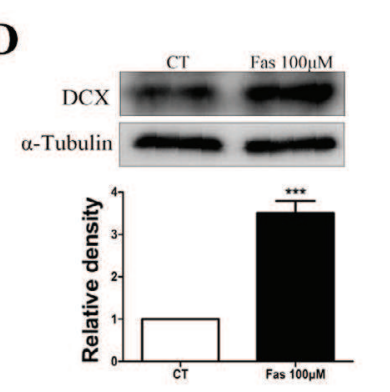

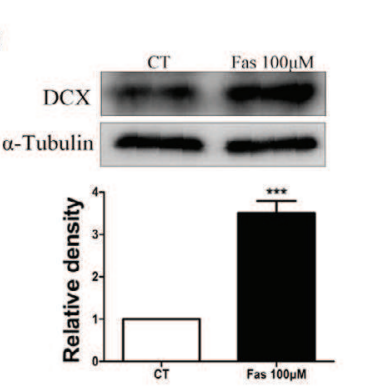

$\mathbf{F}$

B
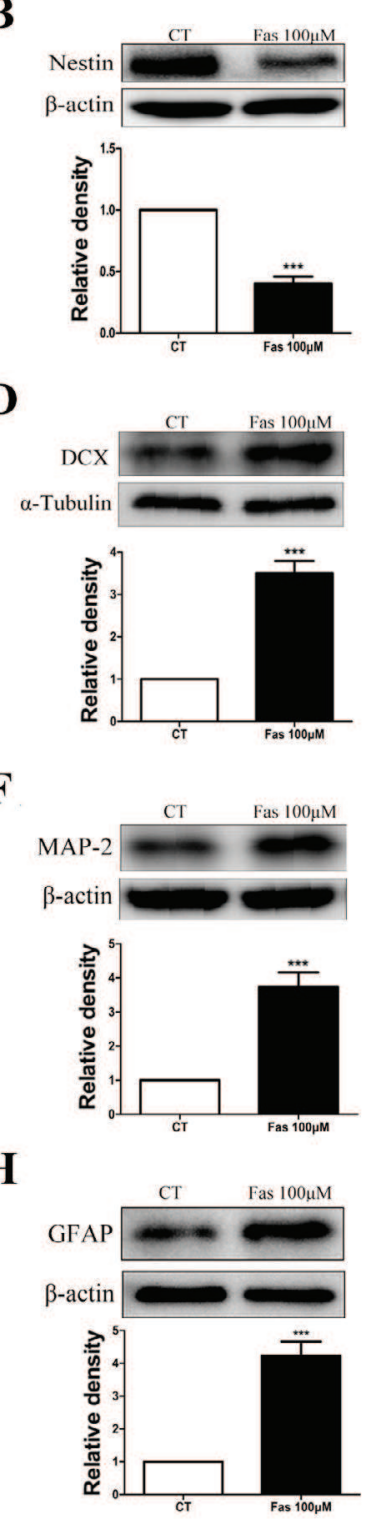

Fig. 4. Fasudil promotes C17.2 cell differentiation after $24 \mathrm{~h}$ of treatment. Immunofluorescence and western blot analyses were applied to evaluate the levels of the neural stem cell marker Nestin (A/B), the immature neuronal marker DCX (C/D), the mature neuronal marker MAP-2 (E/F) and the astrocytic marker GFAP $(\mathrm{G} / \mathrm{H}) .{ }^{* * *} p<0.01$ vs. control group (CT). Scale bar $=10 \mu \mathrm{m}$.

(Fig. 4A/B) markedly decreased in the fasudil treatment group compared with that in the control group $(p<0.01)$. In contrast, the expression of DCX (Fig. 4C/D), MAP-2 (Fig. 4E/F) and GFAP (Fig. 4G/H) significantly increased after fasudil treatment $(p<0.01)$. Furthermore, the percentage of Nestin ${ }^{+}$cells decreased, whereas that of $\mathrm{DCX}^{+}, \mathrm{MAP}^{+}$and $\mathrm{GFAP}^{+}$cells increased $(p<0.01)$.

Fasudil modulated the Notch signalling pathway

To determine whether the Notch signalling pathway was involved in fasudil-induced differentiation of NSCs, we examined the expression levels of Notch 1 and Hes 1 in C17.2 cells with or without fasudil treatment. As shown in Fig. 5, fasudil treatment obviously 


\section{Cellular Physiology Cell Physiol Biochem 2015;36:531-541 \begin{tabular}{l|l} 
DOI: 10.1159/000430118 & \\
and Biochemistry Published online: May 18, 2015 & $\begin{array}{l}\text { O } 2015 \mathrm{~S} \text {. Karger AG, Basel } \\
\text { www.karger.com/cpb }\end{array}$
\end{tabular} \\ Chen et al.: Fasudil Promotes C17.2 Cells Neurite Outgrowth and Differentiation}

Fig. 5. Fasudil decreases the levels of Notch 1 and Hes 1 in C17.2 cells. C17.2 cells were treated with fasudil $(100 \mu \mathrm{M})$ for 1,3 , 6, 12 and $24 \mathrm{~h}$. Protein extracts were prepared for western blot analysis. ${ }^{*} p<0.05$ and ${ }^{* * *} p<0.01$ vs. $0 \mathrm{~h}$ group.
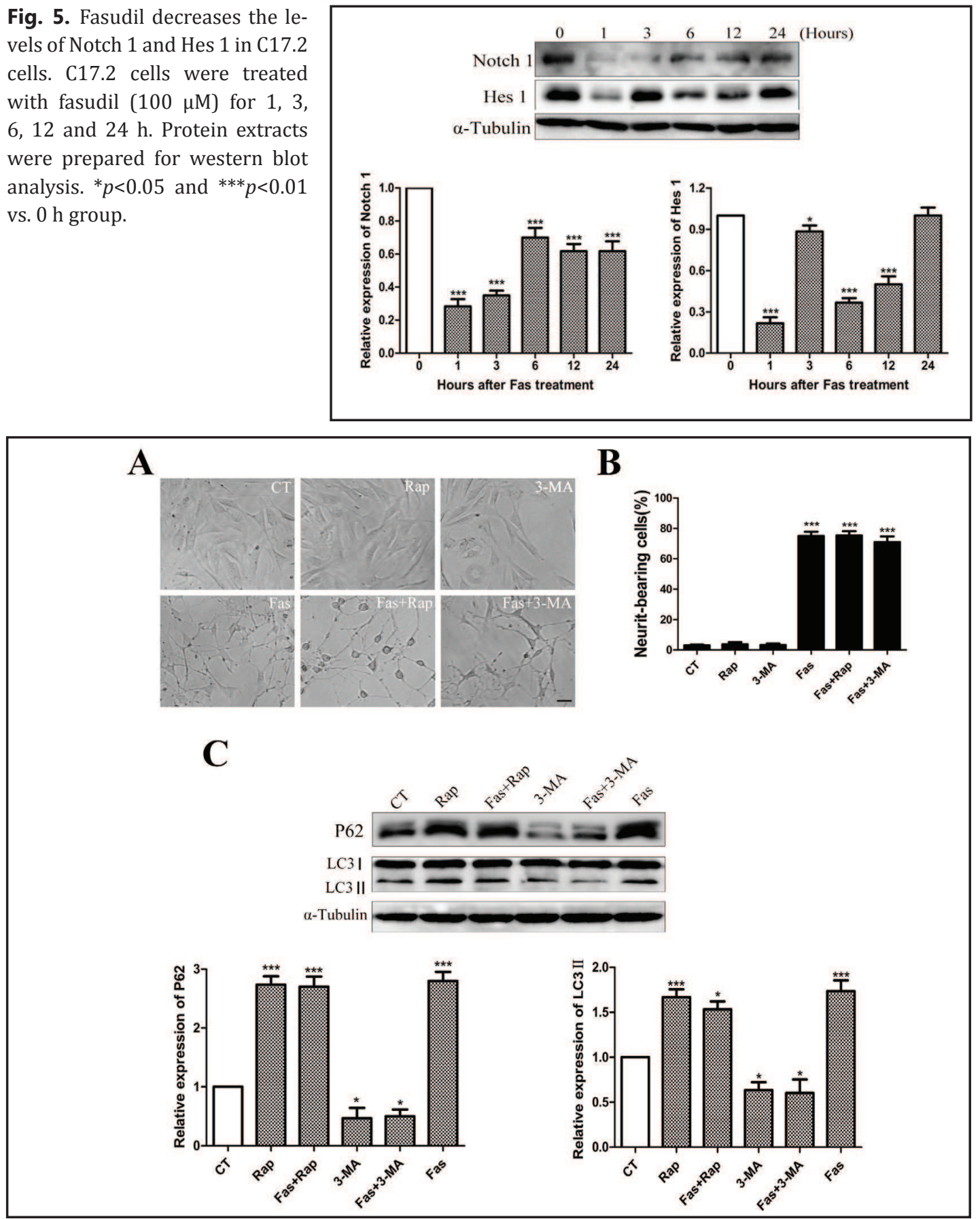

Fig. 6. Autophagy inhibition and induction did not affect neurite outgrowth in C17.2 cells. C17.2 cell morphology changed after treatment with fasudil (100 $\mu \mathrm{M}$, Fas), the autophagy inducer rapamycin (1 $\mu \mathrm{M}, \mathrm{Rap})$, fasudil+rapamycin (Fas+Rap), the autophagy inhibitor 3-MA (10 mM, 3-MA) and Fasudil+3-MA (Fas+3MA). Cell morphology changes were observed under a light microscope $(200 \times)$ (A), and the percentage of neurite-bearing cells was counted (B). Western blot analysis of the expression levels of the autophagy markers P62 and LC3 in C17.2 cells (C). ${ }^{*} p<0.05$ and ${ }^{* * *} p<0.01$ vs. control group (CT). Scale bar=50 $\mu$ m.

lowered the expression levels of both Notch 1 and Hes 1 in a time-dependent manner. The expression levels of Notch 1 notably decreased by $77 \%, 60 \%, 31 \%, 34 \%$ and $32 \%$ following fasudil treatment for $1,3,6,12$ and $24 \mathrm{hs}$, respectively, when compared with untreated cells $(p<0.01)$. In addition, the expression levels of Hes 1 also prominently decreased by $81 \%$, 


\section{Cellular Physiology Cell Physiol Biochem 2015;36:531-541 \\ \begin{tabular}{ll|l} 
and Biochemistry $10.1159 / 000430118$ & $\begin{array}{l}\text { Published online: May 18, } 2015 \\
\text { Po } 2015 \text { S. Karger AG, Basel } \\
\text { www.karger.com/cpb }\end{array}$ \\
\hline
\end{tabular}}

$12 \%, 61 \%, 49 \%$ and increased by $1 \%$ following fasudil treatment for 1, 3, 6, 12 and 24 hs, respectively, when compared with untreated cells ( $p<0.01, p<0.05$ or no difference).

\section{3-MA did not affect fasudil-induced neurite outgrowth in NSCs and rapamycin could not} induce neurite outgrowth as fasudil did

To determine whether autophagy was involved in the observed neurite outgrowth in C17.2 cells, the autophagy inhibitor 3-MA and the autophagy inducer rapamycin were applied. Both 3-MA and rapamycin had no effect on the observed morphological changes of the cells. The percentage of neurite-bearing cells did not change after rapamycin treatment compared with that of untreated cells (Fig. 6A/B). Additionally, no change in the ratio of neurite-bearing cells was found in the cells treated with fasudil+3-MA compared with the cells treated with fasudil alone (Fig. 6A/B). Western blot analysis (Fig. 6C) was used to detect the protein levels of LC3II and p62, whose levels changed as we expected; fasudil and rapamycin treatment increased the levels of LC3II and p62 expression, and 3-MA decreased these levels after treatment for $12 \mathrm{~h}$.

\section{Discussion}

In this study, we examined the neurite outgrowth in C17.2 cells induced by fasudil in a dose- and time-dependent manner. Moreover, fasudil was not cytotoxic to C17.2 cells and caused these cells to differentiate into immature or mature neuronal cells and astrocytes through modulating the Notch signalling pathway. Autophagy was also potentiated in C17.2 cells by fasudil; however, no effect on neurite outgrowth was observed when autophagy was induced or inhibited.

We found that the observed neurite outgrowth could be reversed by washing off fasudil and further incubating the cells for $12 \mathrm{~h}$ (Fig. 1 and Fig. 2). The outgrowth of neurite induced by lower concentration of fasudil might be due to its Rho kinase inhibition, which plays a crucial role in cytoskeleton construction $[27,28]$. Very recently, two other reports demonstrated that Rho/ROCK pathway is involved with neurite outgrowth in NT2 and PC12 cells $[29,30]$. But it is interesting that why the neurite will not retract when cells exposed to high concentration of fasudil $(100 \mu \mathrm{M})$. At such concentration, fasudil can also inhibit other kinases, including PKA [31]. Further studies are necessary to uncover the exact mechanism.

The Notch signalling pathway is widely believed to be tightly associated with NSC differentiation and proliferation. The Notch signalling pathway is activated for NSC selfrenewal, and NSCs switch from proliferation to differentiation when Notch activity decreases [16]. In our study, the expression levels of Notch 1 and Hes 1 , which were examined by Western blot, both significantly decreased. Notably, the expression level of Hes 1 markedly increased after the cells were treated with fasudil for $6 \mathrm{~h}$ compared with other treatment groups; this increase may be due to the oscillation of Hes 1 expression [20]. NSC differentiation and proliferation is influenced by many other factors such as cytokine signaling 1 [32], Ketamine [33] and cell volume change [34].

The Notch signalling pathway plays a crucial role in the development of the CNS and in the regulation of NSC proliferation, survival, self-renewal and differentiation, is involved in many neurodegenerative diseases such as AD and Parkinson's disease (PD) [23, 35]. Inhibiting Notch signalling to promote NSC differentiate into dopaminergic neurons may provide a cell replacement therapy for PD [35]. Additionally, down-regulating Notch 1 may reduce tau aggregates in $\mathrm{AD}$ to improve the cognitive function of $\mathrm{AD}$ patients [23]. Thus, Notch 1 is a potential therapeutic target for neurodegenerative diseases. Additionally, a fancy Notch-ROCK pathway is involved in immature cell self-renewal and differentiation [36]. Our study suggested that fasudil, which inhibits Notch signalling and the ROCK pathway, may be a promising potent strategy for treating neurodegenerative diseases.

The mechanisms involved in neurite outgrowth and NSC differentiation induced by fasudil are complicated and remain unclear. Some evidence has indicated that autophagy 


\section{Cellular Physiology Cell Physiol Biochem 2015;36:531-541 \begin{tabular}{c|c|}
\hline DOI: 10.1159/000430118 & O 2015 S. Karger AG, Basel \\
\hline
\end{tabular} and Biochemistry Published online: May 18, 2015 www.karger.com/cpb \\ Chen et al.: Fasudil Promotes C17.2 Cells Neurite Outgrowth and Differentiation}

is involved in neurite outgrowth [37] and that fasudil can potentiate autophagy [13]. Thus, we determined whether autophagy is involved in fasudil-induced neurite outgrowth. Although fasudil and rapamycin treatment induced autophagy, only the cells treated with fasudil displayed neurite outgrowth. Furthermore, autophagy was inhibited when cells were treated with both fasudil and 3-MA; however, no effect on neurite outgrowth was observed in C17.2 cells most likely because the concentration of fasudil was so high that more than one signalling pathway was affected simultaneously. In addition, the conventional clinical dosage of fasudil is $30 \mathrm{mg}$ per day, and its peak concentration in human plasma is approximately $190 \mathrm{ng} / \mathrm{ml}$ [38] or approximately $58 \mu \mathrm{M}$. Thus, in our study, the cells were treated with a concentration of fasudil that is somewhat higher than that in vivo. Moreover, fasudil has a low blood-brain barrier transmittance due to its poor lipid solubility [39]. However, our findings still indicate that fasudil may possess the potential for multi-target treatment in diseases, particularly in CNS disorders.

As a clinical medicine, fasudil is primarily used to dilate arteries in SAH patients. Fasudil also plays multiple roles in disease states, such as suppressing angiogenesis to inhibit tumour growth [2], improving neurological function recovery in neurodegenerative disease [5] and preserving the motor neurons to treat spinal and muscle atrophy [28]. Fasudil may be a multi-target medicine that regulates not only ROCK but also the ERK signal pathway [2], and Akt [40] and Wnt signalling [41]. Thus, with multiple targets, fasudil may be a promising medicine for CNS disorders.

In summary, the present study demonstrated that fasudil stimulates neurite outgrowth in C17.2 cells and promotes their differentiate into neuronal cells through modulating Notch signalling but not autophagy, suggesting that fasudil may be a promising medicine to exert its multi-targeted activity in CNS disorder treatment.

\section{Disclosure Statement}

None of the authors of this paper has a financial or personal relationship with other people or organisations that could inappropriately influence or bias the content of this paper. The authors report no potential conflicts of interest.

\section{Acknowledgments}

This research was supported by grants from the Fundamental Research Funds for Guangdong Provincial Project of Science \& Technology (No. 2012B031800356) to Anmin Liu.

\section{References}

1 Deng L, Li G, Li R, Liu Q, He Q, Zhang J: Rho-kinase inhibitor, fasudil, suppresses glioblastoma cell line progression in vitro and in vivo. Cancer Biol Ther 2010;9:875-884.

2 Nakabayashi H, Shimizu K: HA1077, a Rho kinase inhibitor, suppresses glioma-induced angiogenesis by targeting the Rho-ROCK and the mitogen-activated protein kinase kinase/extracellular signal-regulated kinase (MEK/ERK) signal pathways. Cancer Sci 2011;102:393-399.

3 Huentelman MJ, Stephan DA, Talboom J, Corneveaux JJ, Reiman DM, Gerber JD, Barnes CA, Alexander GE, Reiman EM, Bimonte-Nelson HA: Peripheral delivery of a ROCK inhibitor improves learning and working memory. Behav Neurosci 2009;123:218-223.

4 Ding J, Li QY, Yu JZ, Wang X, Sun CH, Lu CZ, Xiao BG: Fasudil, a Rho kinase inhibitor, drives mobilization of adult neural stem cells after hypoxia/reoxygenation injury in mice. Mol Cell Neurosci 2010;43:201-208.

5 Ding J, Yu JZ, Li QY, Wang X, Lu CZ, Xiao BG: Rho kinase inhibitor Fasudil induces neuroprotection and neurogenesis partially through astrocyte-derived G-CSF. Brain Behav Immun 2009;23:1083-1088. 


\section{Cellular Physiology Cell Physiol Biochem 2015;36:531-541 \begin{tabular}{c|c|}
\hline DOI: 10.1159/000430118 & (O) 2015 S. Karger AG, Basel \\
\hline
\end{tabular} and Biochemistry Published online: May 18, $2015 \quad$ www.karger.com/cpb \\ Chen et al.: Fasudil Promotes C17.2 Cells Neurite Outgrowth and Differentiation}

6 Cheng F, Lu XC, Hao HY, Dai XL, Qian TD, Huang BS, Tang LJ, Yu W, Li LX: Neurogenin 2 converts mesenchymal stem cells into a neural precursor fate and improves functional recovery after experimental stroke. Cell Physiol Biochem 2014;33:847-858.

7 Li M, Liu X, Yue H, Xiong W, Gu J, Xu M: Transplantation of N -acetyl aspartyl-glutamate synthetaseactivated neural stem cells after experimental traumatic brain injury significantly improves neurological recovery. Cell Physiol Biochem 2013;32:1776-1789.

8 Satoh S, Kawasaki K, Hitomi A, Ikegaki I, Asano T: Fasudil protects cultured N1E-115 cells against lysophosphatidic acid-induced neurite retraction through inhibition of Rho-kinase. Brain Res Bull 2011;84:174-177.

9 Cheng C, Webber CA, Wang J, Xu Y, Martinez JA, Liu WQ McDonald D, Guo GF, Nguyen MD, Zochodne DW: Activated RHOA and peripheral axon regeneration. Exp Neurol 2008;212:358-369.

10 Lingor P, Teusch N, Schwarz K, Mueller R, Mack H, Bahr M, Mueller BK: Inhibition of Rho kinase (ROCK) increases neurite outgrowth on chondroitin sulphate proteoglycan in vitro and axonal regeneration in the adult optic nerve in vivo. J Neurochem 2007;103:181-189.

11 Chin TY, Kao CH, Wang HY, Huang WP, Ma KH, Chueh SH: Inhibition of the mammalian target of rapamycin promotes cyclic AMP-induced differentiation of NG108-15 cells. Autophagy 2010;6:1139-1156.

12 Zeng M, Zhou JN: Roles of autophagy and mTOR signaling in neuronal differentiation of mouse neuroblastoma cells. Cell Signal 2008;20:659-665.

13 Iorio F, Isacchi A, di Bernardo D, Brunetti-Pierri N: Identification of small molecules enhancing autophagic function from drug network analysis. Autophagy 2010;6:1204-1205.

14 Iorio F, Bosotti R, Scacheri E, Belcastro V, Mithbaokar P, Ferriero R, Murino L, Tagliaferri R, Brunetti-Pierri $\mathrm{N}$, Isacchi A, di Bernardo D: Discovery of drug mode of action and drug repositioning from transcriptional responses. Proc Natl Acad Sci U S A 2010;107:14621-14626.

15 Noah TK, Shroyer NF: Notch in the intestine: regulation of homeostasis and pathogenesis. Annu Rev Physiol 2013;75:263-288.

16 Wang Z, Sugano E, Isago H, Murayama N, Tamai M, Tomita H: Notch signaling pathway regulates proliferation and differentiation of immortalized Muller cells under hypoxic conditions in vitro. Neuroscience 2012;214:171-180.

17 Song Y, Lu B: Interaction of Notch signaling modulator Numb with alpha-Adaptin regulates endocytosis of Notch pathway components and cell fate determination of neural stem cells. J Biol Chem 2012;287:1771617728.

18 Redmond L, Oh SR, Hicks C, Weinmaster G, Ghosh A: Nuclear Notch1 signaling and the regulation of dendritic development. Nat Neurosci 2000;3:30-40.

19 Kageyama R, Ohtsuka T, Kobayashi T: The Hes gene family: repressors and oscillators that orchestrate embryogenesis. Development 2007;134:1243-1251.

20 Hirata H, Yoshiura S, Ohtsuka T, Bessho Y, Harada T, Yoshikawa K, Kageyama R: Oscillatory expression of the bHLH factor Hes1 regulated by a negative feedback loop. Science 2002;298:840-843.

21 Liu Q Fan X, Zhu J, Xu G, Li Y, Liu X: Co-culturing improves the OGD-injured neuron repairing and NSCs differentiation via Notch pathway activation. Neurosci Lett 2014;559:1-6.

22 Kiparissides A, Koutinas M, Moss T, Newman J, Pistikopoulos EN, Mantalaris A: Modelling the Delta1/ Notch1 pathway: in search of the mediator(s) of neural stem cell differentiation. PLoS One 2011;6:e14668.

23 Nagarsheth MH, Viehman A, Lippa SM, Lippa CF: Notch-1 immunoexpression is increased in Alzheimer's and Pick's disease. J Neurol Sci 2006;244:111-116.

24 Ryder EF, Snyder EY, Cepko CL: Establishment and characterization of multipotent neural cell lines using retrovirus vector-mediated oncogene transfer. J Neurobiol 1990;21:356-375.

25 Lundqvist J, El Andaloussi-Lilja J, Svensson C, Gustafsson Dorfh H, Forsby A: Optimisation of culture conditions for differentiation of C17.2 neural stem cells to be used for in vitro toxicity tests. Toxicol In Vitro 2013;27:1565-1569.

26 Decker T, Lohmann-Matthes ML: A quick and simple method for the quantitation of lactate dehydrogenase release in measurements of cellular cytotoxicity and tumor necrosis factor (TNF) activity. J Immunol Methods 1988;115:61-69.

27 Guan R, Xu X, Chen M, Hu H, Ge H, Wen S, Zhou S, Pi R: Advances in the studies of roles of Rho/Rho-kinase in diseases and the development of its inhibitors. Eur J Med Chem 2013;70:613-622. 


\section{Cellular Physiology Cell Physiol Biochem 2015;36:531-541 \begin{tabular}{l|l}
\hline DOI: 10.1159/000430118 & C 2015 S. Karger AG, Basel
\end{tabular} and Biochemistry Published online: May 18, $2015 \quad$ www.karger.com/cpb \\ Chen et al.: Fasudil Promotes C17.2 Cells Neurite Outgrowth and Differentiation}

28 Chen M, Liu A, Ouyang Y, Huang Y, Chao X, Pi R: Fasudil and its analogs: a new powerful weapon in the long war against central nervous system disorders? Expert Opin Investig Drugs 2013;22:537-550.

29 Lu XC, Zheng JY, Tang LJ, Huang BS, Li K, Tao Y, Yu W, Zhu RL, Li S, Li LX: MiR-133b Promotes neurite outgrowth by targeting RhoA expression. Cell Physiol Biochem 2015;35:246-258.

30 Roloff F, Scheiblich H, Dewitz C, Dempewolf S, Stern M, Bicker G: Enhanced Neurite Outgrowth of Human Model (NT2) Neurons by Small-Molecule Inhibitors of Rho/ROCK Signaling. PLoS One 2015;10:e0118536.

31 Chen MH, Liu Q Liu AM, Tan M, Xie ZY, Uri A, Chen ZW, Huang GY, Sun Y, Ge H, Liu PQ, Li M, Li XS, Wen SJ, Pi RB: Simply combining fasudil and lipoic acid in a novel multitargeted chemical entity potentially useful in central nervous system disorders. Rsc Advances 2014;4:37266-37269.

32 Cui M, Dai B, Xin JY, He JQ Feng SQ: Overexpression of suppressors of cytokine signaling 1 promotes the neuronal differentiation of C17.2 neural stem cells. Cell Physiol Biochem 2014;33:528-538.

33 Wu YQ, Liang T, Huang H, Zhu YZ, Zhao PP, Xu CM, Liu L, Shi XT, Hu Y, Huang L, Zhou CH: Ketamine inhibits proliferation of neural stem cell from neonatal rat hippocampus in vitro. Cell Physiol Biochem 2014;34:1792-1801.

34 Hernandez-Benitez R, Sedeno-Cortes A, Ramos-Mandujano G, Pasantes-Morales H: Regulatory volume decrease in neural precursor cells: taurine efflux and gene microarray analysis. Cell Physiol Biochem 2014;34:2038-2048.

35 Ding YX, Wei LC, Wang YZ, Cao R, Wang X, Chen LW: Molecular manipulation targeting regulation of dopaminergic differentiation and proliferation of neural stem cells or pluripotent stem cells. CNS Neurol Disord Drug Targets 2011;10:517-528.

36 Yugawa T, Nishino K, Ohno S, Nakahara T, Fujita M, Goshima N, Umezawa A, Kiyono T: Noncanonical NOTCH signaling limits self-renewal of human epithelial and induced pluripotent stem cells through ROCK activation. Mol Cell Biol 2013;33:4434-4447.

37 Ashabi G, Ahmadiani A, Abdi A, Abraki SB, Khodagholi F: Time course study of Abeta formation and neurite outgrowth disruption in differentiated human neuroblastoma cells exposed to H2O2: protective role of autophagy. Toxicol In Vitro 2013;27:1780-1788.

38 Chen H, Lin Y, Han M, Bai S, Wen S: Simultaneous quantitative analysis of fasudil and its active metabolite in human plasma by liquid chromatography electro-spray tandem mass spectrometry. J Pharm Biomed Anal 2010;52:242-248.

39 He FC, Li SX, Zhao ZQ, Dong JP, Liu WZ, Su RQ: [Simultaneous quantitative analysis of four lignanoids in Schisandra chinensis by quantitative analysis of multi-components by single marker]. Yao Xue Xue Bao 2012;47:930-933.

40 Wu J, Li J, Hu H, Liu P, Fang Y, Wu D: Rho-kinase inhibitor, fasudil, prevents neuronal apoptosis via the Akt activation and PTEN inactivation in the ischemic penumbra of rat brain. Cell Mol Neurobiol 2012;32:11871197.

41 Li L, Tam L, Liu L, Jin T, Ng DS: Wnt-signaling mediates the anti-adipogenic action of lysophosphatidic acid through cross talking with the Rho/Rho associated kinase (ROCK) pathway. Biochem Cell Biol 2011;89:515-521. 